\title{
79. A Diabetic Strain of the Mouse
}

\author{
By Mitsuo Nakamura \\ Department of Anatomy, Faculty of Medicine, Nagoya University \\ (Comm. by T. KomaI, M.J.A., July 12, 1962)
}

The heredity of diabetes mellitus in man has been studied by many authors. Most of them concluded that the disease is inherited as a Mendelian recessive trait in the majority of cases. However, only few experimental data on the heredity of diabetes mellitus in animals have been reported. Cases of spontaneous diabetes are known in dog, cat and hamster, as well as in the "obese-hyperglycemic" mutant in the mouse. None of these animals except those of the hamster is of a pure strain.

Recent search for diabetics among inbred strains of mice by the author has discovered the present $K K$ strain. This inbred strain which was originally established by Professor K. Kondo (1957) in the Faculty of Agriculture of Nagoya University, has such characteristics as sluggishness, moderate obesity $(30-35$ grams in body weight at the age of 5 months), polyphagia and polyuria. These features also characterize human diabetes mellitus of relatively late onset.

Material and Method. The animals used in this study are the $K K$ mice 2 to 10 months old, and the $C B A, C 57 B L / 6$ and $d d N$ mice 3 to 8 months old as control. They were fed with the Oriental laboratory chow N.M.F. and water under constant temperature $\left(24^{\circ} \mathrm{C}\right)$ and illumination (9: 30 a.m. to 9 p.m.).

Glucose tolerance test. After 12 hours' fasting, the animals were given orally $2 \mathrm{gr}$. of glucose per $\mathrm{kg}$. of body weight. $0.03 \mathrm{cc}$ of blood samples from the tail vein was obtained consecutively at $0,0.5,1$ and $2 \mathrm{hr}$. after the administration of glucose. Blood glucose determination was made by the Hagedorn-Jensen method. Simultaneously, glucosuria test was carried on by the Tes-tape (Lilly).

Histologic method. For examination of pancreas, three staining techniques, namely, Gomori's chromium-hematoxylin-phloxin, Okamoto's zine and Barrnett and Seligman's insulin stains were used. The liver was examined by periodic acid-Schiff reaction and by the hematoxylin-eosin staining, after being fixed in ethanol and $10 \%$ formalin respectively. The eye and kidney were fixed in 10\% formalin and stained with hematoxylin and eosin, while the adrenal was stained similarly after fixation with Ciaccio's solution.

For bioassay of insulin content of the pancreas, the mice had 
been kept in free access to food and water until examination. Extraction was carried out by the technique of Best et al. The pancreases of 3 to 4 animals were pooled. The bioassay of the pancreatic extract for its insulin content was carried out by using fasted (for 24 hours) $d d N$ mice 3 to 4 months old as test animals. Bloodsugar value 1 hour after the intraperitoneal injection of the extract was determined. By comparing these values with those obtained after injection of the standard dose of insulin, the estimation of insulin content in the pancreas was made. The results for 5 test animals were averaged, and the standard deviation was calculated.

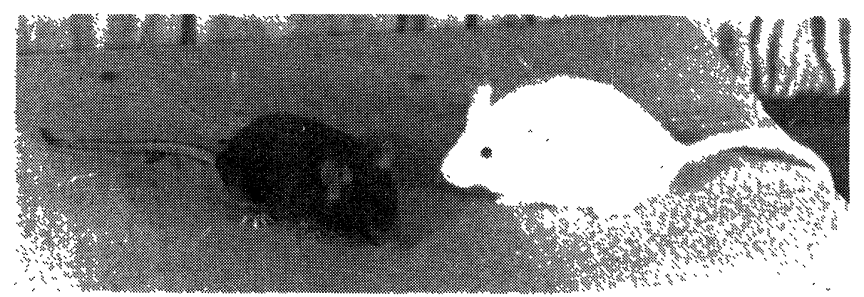

Fig. 1. $K K$ and $C 57 B L / 6$ mice right: male $K K$ mouse, 7 month old.

left : male $C 57 B L / 6$ mouse, 7 months old.
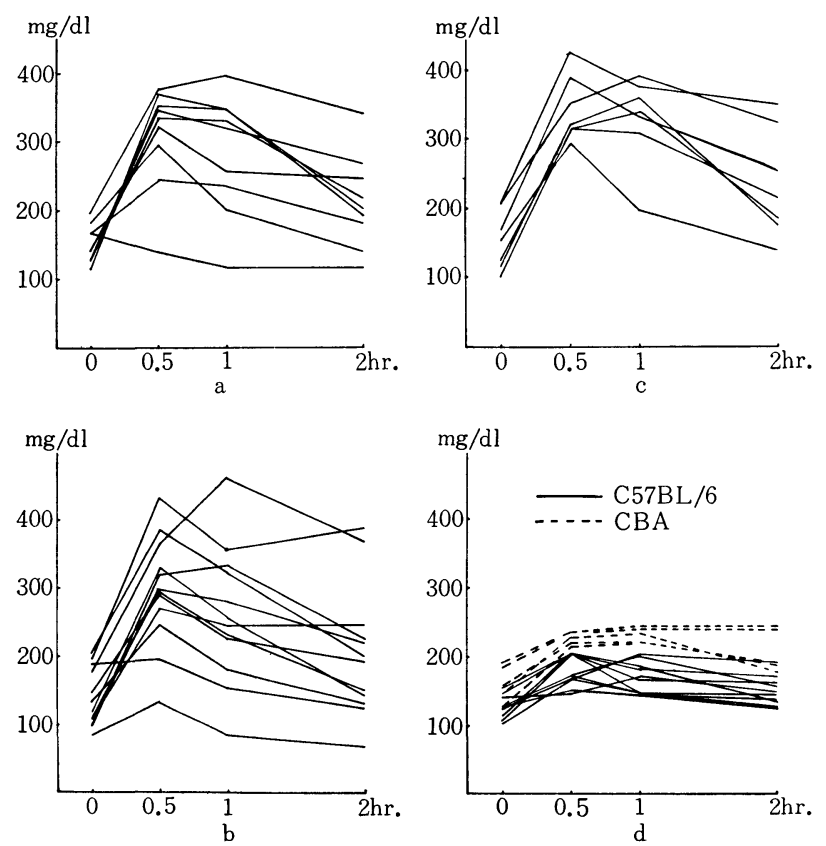

Fig. 2. Glucose tolerance test

a) $K K$ mice below 3 months of age

b) $K K$ mice 3 to 4 month old

c) $K K$ mice 5 to 8 month old

d) $C 57 B L / 6$ and $C B A$ mice as controls, aged 3,4 and 5 months respectively. 
Result. Glucose tolerance tests were carried out on $28 K K$ (ㅇ 14 우 14), $10 C 5 \% B L / 6$ (오 7 우 3) and $5 C B A$ (소 2 우 3) mice (Fig. 2). The majority of $K K$ mice showed blood-sugar curves similar to those of human diabetics, while the mice of the other strains gave normal curves. Especially, all the $K K$ mice, older than 5 months examined, showed "diabetic" blood sugar curves. Of the younger $K K$ mice, all males, as well as 7 of the 10 females examined gave "diabetic" curves. The majority of the $K K$ mice showed glucosuria as their blood sugar content exceeded $240 \mathrm{mg} / \mathrm{dl}$, whereas no such symptom was found in animals of the other strains. Among the $K K$ mice aged more than 7 months, some individuals displayed persistent glucosuria.

Histological examinations of the pancreas, liver and eyes were made on $27 K K$ (소 22 우 5), $9 C B A$ (소 5 우 4) and $9 d d N$ (송 2 우 7) mice. Prior to the sacrifice of the animals, blood samples were obtained from the tail vein, and glucose determination was made. Thus, the values of non-fasting blood-sugar levels were obtained.

In the chromium-hematoxylin and phloxin stained pancreas tissues of $K K$ mice, the degranulation of $\beta$ cells, the hypertrophy of islets and the sinusoid dilatation of blood capillaries within the islets were noticed. The extent of these changes varied approximately parallel to the non-fasting blood sugar levels. (Non-fasting blood sugar value ranged from 150 to 380 in $K K$ mice.)

In $K K$ mice, the pancreatic islet was found to be deficient in histochemically demonstrable zinc content, sometimes even to nothing. In contrast, the insulin content within the islets, as far as could be histochemically detected, did not show any appreciable change.

The livers of $K K$ mice showed fat deposition and decrease in glycogen content.

In the eyes of the mice, the retina was reduced in thickness. Two 7-months-old individuals had lenses that had undergone cataractic changes. Adrenals and kidneys of the $K K$ ( 17 o f 7) and $C 57 B L / 6$ (오 3 우 2) mice were also histologically observed. In $K K$ mice, the adrenals had diminished in size, with thinned cortex. Furthermore, a slight fibrosis was detected in glomerulus of the kidneys.

Finally, insulin was extracted from pancreases of $K K$ and $C 5^{r} B L / 6$ mice and the approximate amount of the hormone was determined by bioassay of $d d N$ mice ( 5 animals/l sample). The results obtained are indicated in Table I. The $K K$ mice have significantly higher amount of insulin per gram of the pancreatic tissue-about four times as much as those of $C 5 \% B L / 6$ mice.

Discussion. The hyperglycemic state observed in the $K K$ mice closely resembles the diabetes mellitus of the adult type in man with 
Table I

\begin{tabular}{|c|c|c|c|c|c|}
\hline \multirow{2}{*}{\multicolumn{2}{|c|}{ Mice }} & \multirow{2}{*}{$\underset{\text { (Months) }}{\text { Age }}$} & \multirow{2}{*}{$\begin{array}{l}\text { Blood sugar } \\
\text { value }(\mathrm{mg} / \mathrm{dl})\end{array}$} & \multicolumn{2}{|c|}{ Insulin content } \\
\hline & & & & (I. U./gr.) & S. D. \\
\hline \multirow{4}{*}{\multicolumn{2}{|c|}{$C 57 B L / 6$ 令 }} & 5 & 116 & 0.7 & 0.23 \\
\hline & & 5 & 120 & & \\
\hline & & 5 & 120 & & \\
\hline & & 5 & 124 & & \\
\hline \multirow{4}{*}{\multicolumn{2}{|c|}{$C 5^{7} B L / 6$ 今 }} & 5 & 124 & 0.6 & 0.25 \\
\hline & & 5 & 128 & & \\
\hline & & 5 & 124 & & \\
\hline & & 5 & 130 & & \\
\hline \multirow{4}{*}{\multicolumn{2}{|c|}{$C 57 B L / 6$ 우 }} & 5 & 128 & 0.7 & 0.56 \\
\hline & & 5 & 116 & & \\
\hline & & 5 & 130 & & \\
\hline & & 5 & 128 & & \\
\hline \multirow[t]{4}{*}{$K K$} & 今 & 9 & 326 & 2.3 & 0.85 \\
\hline & & 8 & 236 & & \\
\hline & & 7 & 214 & & \\
\hline & & 7 & 317 & & \\
\hline \multirow[t]{3}{*}{$K K$} & 우 & 8 & 160 & 2.5 & 0.42 \\
\hline & & 8 & 164 & & \\
\hline & & 8 & 168 & & \\
\hline \multirow[t]{3}{*}{$K K$} & $\hat{o}$ & 3 & 190 & 2.2 & 0.50 \\
\hline & & 3 & 208 & & \\
\hline & & 3 & 208 & & \\
\hline \multirow[t]{3}{*}{$K K$} & 우 & 3 & 182 & 2.5 & 1.27 \\
\hline & & 3 & 168 & & \\
\hline & & 3 & 178 & & \\
\hline
\end{tabular}

respect to the following points:-(1) moderate obesity, polyphagia and polyuria; (2) the similarity of glucose tolerance curves of most $K K$ mice to those of human diabetes - the persistent glucosuria often detected in old $K K$ mice is a conclusive evidence for diabetes; (3) the histologic findings, especially of pancreas, corresponding to those found in the patient of diabetes of the adult human type; (4) the excessive amount of insulin present in pancreas, like in human adulttype diabetes.

As to the differences between the $K K$ and the obese mice, the following points are to be mentioned:-(1) The obese mice are sterile, while the $K K$ mice are perfectly fertile. (2) The obese mice are abnormally fat, which seems to be due to severe hormonal disturbance. On the contrary, $K K$ mice are moderately obese like most 
patients of diabetes mellitus of the human adult type. (3) Hyperglycemia of $K K$ mice appears to progress with age, whereas in the obese mice such a tendency has never been noticed. (4) Histologic changes may be found in organs other than pancreas and liver in $K K$ mice, while in obese mice such changes have not been observed.

These differences seem to show that the diabetes-like symptoms of the $K K$ mice are caused by a gene or genes other than " $o b$ ".

From what has been described above, it is very likely that the $K K$ mice will make an excellent material for experimental researches in the etiology, therapy and genetics of diabetes mellitus of man and animals.

The details of histologic findings will be published elsewhere in near future.

Acknowledgement. The author wishes to express his gratitude to Prof. Kazumaro Yamada in the Faculty of Medicine, Nagoya University, for his guidance and encouragement, and to Prof. Kyoji Kondo in the Faculty of Agriculture, Nagoya University, for the supply of $K K$ mice. To Prof. Tsutomu Sugahara in the Faculty of Medicine, Kyoto University, the author is indebted for the supply of mice of control strains and also for valuable suggestions on genetics.

\section{References}

1) Barrnett, R. I., Marshall, R. B., and Seligman, A. M.: Histochemical demonstration of insulin in the islets of Langerhans, Endocrinology, 57, 419 (1955).

2) Best, C. H., Jephcott, C. M., and Scott, D. A.: Insulin in tissue other than the pancreas, Am. J. Physiol., 100, 275 (1932).

3) Bleisch, V. R., Mayer, J., and Dickie, M. M.: Familial diabetes mellitus in mice associated with insulin resistence, obesity and hyperplasia of the islands of Langerhans, Am. J. Path., 28, 369 (1952).

4) Gomori, G.: A differential stain for cell types in the pancreatic islets, Am. J. Path., 15, 497 (1939).

5) Ingalls, A. M., Dickie, M. M., and Snell, G. D.: Obese, A new mutation in the house mouse, J. Heredity, 41, 317 (1950).

6) Kondo, K., Nozawa, K., Tomita, T., and Ezaki, K.: Inbred strains resulting from Japanese mice, Bulletin of the experimental animals (in Japanese), 6, 107 (1957).

7) Meier, H., and Yerganian, G. A.: Spontaneous diabetes mellitus in chinese hamster (Circetulus griseus). 1. Pathological findings, Proc. Soc. Exper. Biol. \& Med., 100, 810 (1959).

8) Maeda, T., Fujiwara, T., and Hironari, K.: Histochemical demonstration of zinc, Bulletin of Kobe Medical College (in Japanese), 5, 97 (1954).

9) Ricket, H. T., Petersen, E. S., Steiner, P. E., and Tupikova, N.: Spontaneous diabetes mellitus in the dog. An account of eight cases, Diabetes, 2, 288 (1953).

10) Schlotthauer, C. F., and Millar, J.A.S.: Diabetes mellitus in dogs and cats, J. Am. Vet. Med. A., 118, 31 (1951). 